\title{
Histological and immunohistochemical study on the effect of Aflatoxin B1 on the ileum of adult male albino rat and possible protective effect of sodium selenite
}

\author{
Original \\ Article \\ Rania Ibrahim Yassien', Omyma Ibraheem Ibraheem Zedan², Mona Mohamed \\ Hassan Soliman ${ }^{3}$ and Nagwa Saad Ghoneim ${ }^{4}$ \\ Departments of ${ }^{1,4}$ Histology, ${ }^{2}$ Anatomy, Faculty of Medicine, Menoufia University, Sheibin \\ El Kom, ${ }^{3}$ Department of Microbiology and Immunology, Veterinary Division, National \\ Research Centre, Doki, Egypt.
}

\begin{abstract}
Background: Aflatoxin B1 is one of dangerous mycotoxins which is produced by Aspergillus fungi. Small intestine especially ileum is important site for absorption and immunity.

Aim: To study histological, ultrastructure and immunohistochemical changes by Aflatoxin B1 on ileum of adult male albino rat and the possible protective effect of sodium selenite.

Materials and Methods: Forty adult male albino rats were used, they were divided into four groups, control group (GI), sodium selenite group (GII), Aflatoxin B1 group (GIII), Aflatoxin B1 and sodium selenite group (GIV). Sections were stained by H\&E, Mallory, Alcain blue and proliferating cell nuclear antigen (PCNA). Ultrathin sections were prepared for electron microscopic study. Morphometric study for different measurement in ileum were done.

Results: Aflatoxin group show marked destruction, disorganization of most villi and crypts, necrosis and vacuolation of covering and lining cells. Hemorrhage, hyalinization and necrosis in submucosa and muscle layers with heavy lymphocytic infiltration are seen. Alcain blue stain show significant decrease in intensity. Goblet cells and PCNA + ve cells reveal significant decrease in their numbers. All sections show marked improvement with selenite treatment, ultrastructure changes are in harmony to light microscope findings.

Conclusion: Aflatoxin B1 has destructive histopathological changes on all layers of ileum and sodium selenite has protective effect against this damage.
\end{abstract}

Key Words: Aflatoxin B1, ileum, sodium selenite.

Revised: 18 February 2020, Accepted: 18 February 2020.

Corresponding Author: Rania Ibrahim Yassien, Ph.D, Department of Histology, Faculty of Medicine, Menoufia University, Sheibin El Kom, Egypt, Tel.: +201028073793, E-mail: raniayassien@yahoo.com

ISSN:2536-9172, June 2020, Vol. 4, No. 1

\section{INTRODUCTION}

Aflatoxins (AFs) are mycotoxins which is produced by various Aspergillus species such as A. Flavus, A. nominus and A. parasiticus. Aflatoxins include aflatoxin B1, B2, G1, G2, M1 and M2. AFB1 which is produced by A. flavus is the most dangerous and abundant mycotoxin ${ }^{[1]}$.

AFs commonly affect food constituents during storage as corn, peanut and cotton seed ${ }^{[2]}$.

AFB1 is proved to make serious health effects in humans and animals as being mutagenic and carcinogenic ${ }^{[3]}$. Furthermore, previous studies recorded the immune toxicity effects of AFB1 which included destructed T-cellimmunity and suppressed phagocytosis by neutrophils and macrophages $^{[4,5]}$.
Selenium is an essential element which is important for several physiological processes in a low dose such as synthesis of coenzyme Q, glutathione peroxidase and thioredoxin reductase ${ }^{[6]}$.

Selenite (Se) is the most widely used inorganic selenium form. It has antioxidant and anti-inflammatory properties in many disease and viral infection ${ }^{[7]}$. Moreover, selenite helps to repair the damaged DNA and to fight cancer ${ }^{[8]}$.

Despite of great importance of ileum for nutrition and health, scanty researches are reported on the effect of Aflatoxins on this part. So, the current study aims to explore the effect of Aflatoxin B1 on the histological structure of ileum of adult male albino rats and the potential protective role of sodium selenite. 


\section{MATERIALS AND METHODS}

\section{Animals}

This study was carried out on 40 adult male albino rats weighing 175-225 g.

Animals were housed in clean properly ventilated cages They were fed on a standard laboratory diet and maintained on a12-h light/dark photoperiod in the animal house of the Faculty of Medicine, Menoufia University, Sheibin El Kom, Menoufia Egypt. The animals were treated in accordance with the approved guidelines of the Animal Care and Ethical Committee of Faculty of Medicine, Menoufia University.

\section{Drugs}

- Sodium selenite powder ( $99 \%$ purity) was purchased from Sigma-Aldrich Corp. (Germany).

- Standards of aflatoxin, methanol, trifluoroacetic acid, acetonitrile, acetic acid, mercaptoethanol and disodium tetra borate were purchased from Sigma Chemical Co (St. Louis, MO, U.S.A.). All the used solvents and chemicals were of High-performance liquid chromatography with fluorescence detection (HPLC-FLD) grade.

- Production of aflatoxin B1: Yousefi et al., ${ }^{[9]}$ :

Toxigenic Aspergillus flavus (lyophilized local strain) was kindly provided from the Mycotoxin Lab., National Research Centre, Dokki, Giza, Egypt. The toxigenic Aspergillus flavus strain was streaked on Potato dextrose agar (PDA) slants at $25^{\circ} \mathrm{C}$ for 10 days. For production of aflatoxins, the toxigenic Aspergillus flavus strain was subcultured on Yeast extract sucrose medium and was incubated at $27^{\circ} \mathrm{C}$ for 15 days afterwards the medium was autoclaved and the fungal mycelia was separated using Whatman filter paper no.1. Aflatoxins B1 were extracted from the remaining filtrate using equal volume of chloroform and the chloroform layer was separated via separating funnel and this step was repeated three times to enable complete extraction of aflatoxins from the filtrate and it was passed through anhydrous sodium sulphate layer. Finally, the chloroform extracts were then concentrated by rotary evaporator till complete dryness ${ }^{[9]}$.

\section{Methods}

Rats were separated into four groups at random way and were received drugs orally dissolved in distilled water by gastric tube as a single daily dose for two weeks.

o Group I (control) composed of 10 rats and were received $1 \mathrm{ml}$ distilled water o Group II (sodium selenite treated) composed of 10 rats and received $(0.25 \mathrm{mg} / \mathrm{kg} \mathrm{bw})^{[10]}$.

o Group III (Aflatoxin B1 treated) composed of 10 rats and received $(0.5 \mathrm{mg} / \mathrm{kg} \mathrm{bw})^{[11]}$.

o Group IV (Aflatoxin B1\& sodium selenite treated): composed of 10 rats which received sodium selenite drug and after two hours Aflatoxin B1 toxin with the same doses and durations as pervious groups.

At the end of the experiment, all animals were sacrificed. The ileum specimen (a segment about $1.5 \mathrm{~cm}$ proximal to the cecum) were quickly excised for preparation and examination

\section{I-Histological study}

A -Light microscopic examination: The ileum was perfused with cold saline, then it was processed to get paraffin blocks. Serial sections of 5-6 $\mu \mathrm{m}$ thickness were cut and prepared for:

1. Hematoxylin and Eosin stain $(\mathrm{H} \& \mathrm{E})^{[12]}$.

2. Mallory trichrome stain for detection of collagen $^{[12]}$.

3. Alcian Blue stain for demonstration of acidic mucus in goblet cells ${ }^{[12]}$.

B-Electron microscopic examination: tissue samples from 4 rats in each group were processed. A small part was excised rapidly (within $1 \mathrm{~min}$ ) and minced into $1 \mathrm{x} 1$ $\mathrm{mm}^{2}$ pieces, primary fixed in $3 \%$ glutaraldehyde and $0.1 \mathrm{M}$ phosphate buffer Then, it was processed to obtain ultrathin grades and was examined with the transmission electron microscope (Seo-Russia) in Tanta E.M Centre at faculty of medicine Tanta University ${ }^{[13]}$.

\section{II- Immunohistochemical study:}

Paraffin blocks were used for detection of proliferating cell nuclear antigen (PCNA) (Mouse monoclonal antibody IHC World Corporation, CA, USA, Catalog Number:SC-56) as a marker of cell proliferation. Negative controls were done by applying same steps but omitting the step of adding the primary antibodies ${ }^{[14]}$.

\section{III - Histomorphometry and statistical studies}

Five fields from different sections of each rat of each group were used to measure:

$(\mathrm{X} 200)$ 
- $\quad$ Number of goblet cells in H\&E stained sections (X200).

- Optical density of Alcian Blue F(X400)

- $\quad$ Number of PCNA-positive cells. (X400)

All measurements were taken using the image analyzer (Leica Q 500 MC program, Wentzler, Germany) in the Anatomy Department, Faculty of Medicine, Menoufia University

\section{Statistical analysis}

Quantitative data were summarized as means and standard deviations (SD). Then they were compared using one-way analysis-of-variance (ANOVA) and were followed by post hoc Tukey test. P-values $<0.05$ were considered statistically significant. Calculations were made on SPSS software version 21 ${ }^{[15]}$.

\section{IV-HPLC-FLD assay:}

HPLC assay was performed utilizing Agilent Technologies 1100 series liquid chromatograph along with an auto sampler and Fluorescence detector. The analytical column was an Eclipse XDB-C18 (150 X $4.6 \mu \mathrm{m} ; 5 \mu \mathrm{m})$ with a $\mathrm{C} 18$ guard column (Agilent, USA).

\section{A. Derivatization:}

The derivatization process was performed as described in [16]. Mixture of 9 acetonitrile: 1 methanol was used to dissolved standard solutions of aflatoxins.

\section{B. HPLC conditions:}

The components of mobile phase were Acetonitrile/ Water/Methanol (1:6:3). Isocratic separation was implemented at room temperature with $1.0 \mathrm{ml} / \mathrm{min}$ flow rate and $20 \mu \mathrm{l}$ from both the standard solutions and the chloroform extracts were injected. The used detector was of fluorescence type at wavelength of $365 \mathrm{~nm}$ for excision and $450 \mathrm{~nm}$ for emission. A $0.45 \mu \mathrm{m}$ Acrodisc syringe filter (Gelman Laboratory, MI) was utilized to filtrate the samples before injection. Matching and analyzing retention times of both standards and samples was done ${ }^{[16]}$.

\section{RESULTS}

\section{H\&E staining::}

H\&E stained sections of ileum of GI (control group) and G II (sodium selenite group) revealed that ileum was formed of four layers mucosa, submucosa, musculosa and serosa.
Villi and crypts of mucosa was covered and lined by simple columnar epithelium cells with apical brush border and basal oval nuclei. Goblet cells appeared with expanded apical part, thin basal part and were resting on basement membrane. Underneath the epithelium lied a connective tissue (C.T.) layer (lamina propria) and a muscle layer (muscularis mucosae). Also, C. T. filled core of villi (Fig 1A-C). The submucosa was formed of C.T which contained blood vessels and lymphatic nodules (lymphoid aggregation). The musculosa consisted of an inner circular and outer longitudinal smooth muscles with acidophilic cytoplasm and central oval nuclei (Fig 1B \& 1C). The ileum was entirely covered by serosa from the outside. Serosa was formed of C. T covered by simple squamous epithelium (Fig 1C). A characteristic feature of the ileum was Payer's patches lying in the mucosa \& submucosa mostly covered by short villi (Fig 1A).

H\&E stained sections of GIII (Aflatoxin group) showed some villi with sloughed degenerated parts of covering epithelium, other villi showed broadening and many villi were destructed with loss of normal organization. There were obliteration and irregularity in lumen of many crypts and necrotized tissue was seen in some lumens of crypts (Figs 1D \& 2D). Also, hemorrhage was seen at bases of some crypts (Fig 2B). C.T core of villi showed lymphocytic infiltration (Fig 2A \& 2D) and dilatation of central lacteals (fig 2C). There was hyalinization in submucosa, thinning and degeneration in muscle layer with dilation and congestion of blood vessels (Fig 2A \& 2B). Some parts of the wall of ileum showed complete destruction of all layers (Fig 1E). There were apparent enlarged of payer's patches and lymphatic nodules with deposition of eosinophilic material (Fig 1D). Some cells showed pyknosis and others with vacuolated cytoplasm. (Fig 2C \& 2D). Some goblet cells showed vacuolation and degeneration. While other goblets revealed complete destruction (Fig 2D)

H\&E stained sections of GIV (sodium selenite \& Aflatoxin group) showed marked improvement and restoration to nearly normal histological picture of villi and crypts, however still shedding, degeneration and damage of some cells with lymphocytic infiltration were seen (Fig 2E). 

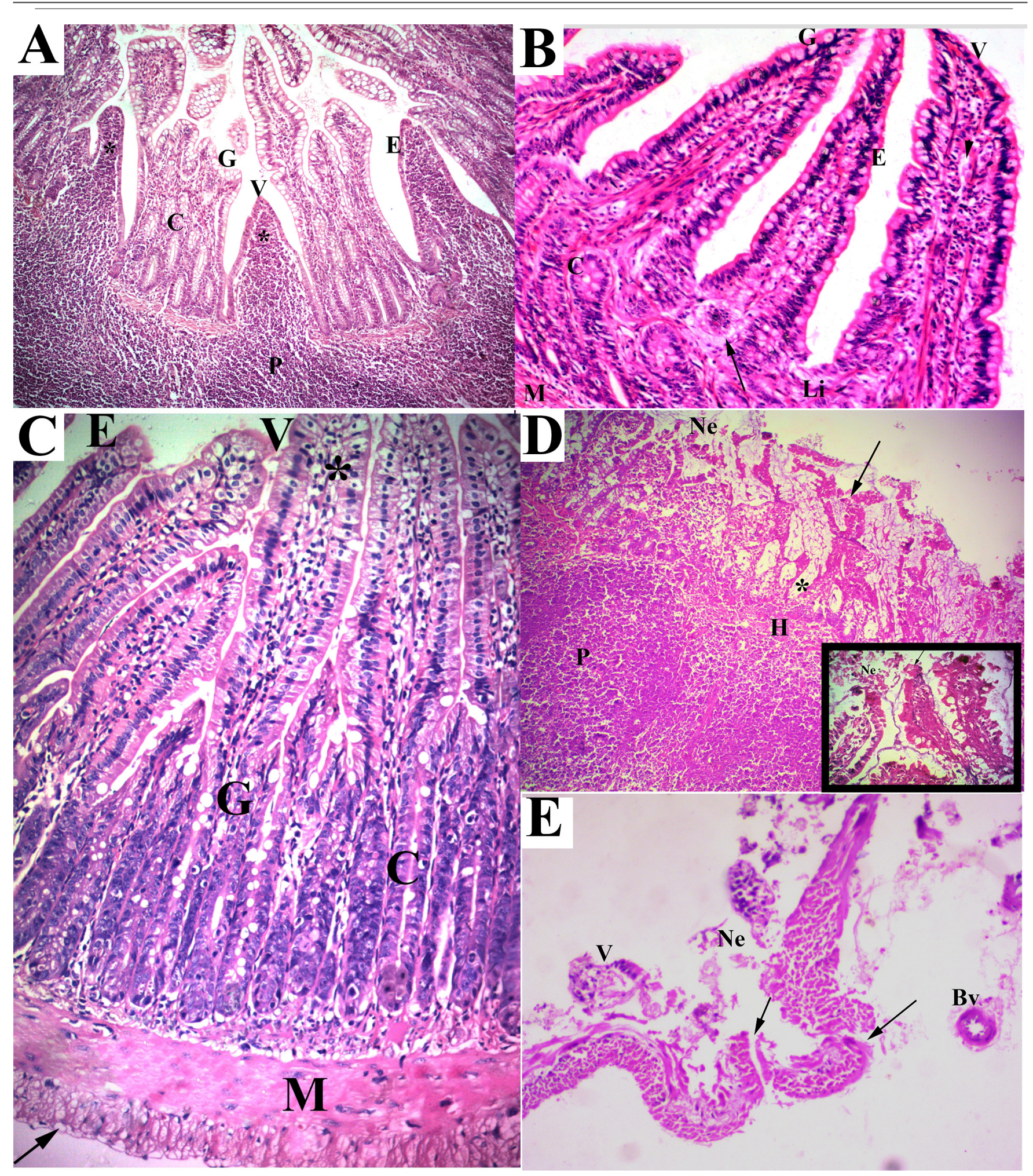

Fig 1: Photomicrograph of H\&E stained sections in rat ileum from:

(A\&B) control group showing mucosa with villi $(V)$ and crypts $(C)$ covered and lined by columnar absorptive cells (E) cells, goblet $(G)$ cells, C.T fill villi (*) with central lacteal (arrow head). Lamina propria (Li) with lymphatic nodules (arrow), payers' patch (P) covered by short villi and muscle layer (M)with acidophilic cytoplasm are shown (X200).

C) (GII) showing mucosa with villi (V) and crypts (C) columnar absorptive cells (E) cells, goblet (G) cells, C. T fill villi (*). Muscle layer (M) and serosa (arrow) are shown (X200).

D) (GIII) showing deposition of eosinophilic hyaline $(\mathrm{H})$ material in enlarged payer's patches $(\mathrm{P})$, destructed villi (arrow) and destructed crypts $(*)$ with loss of cells and necrotic cells $(\mathrm{Ne})$ in the lumen (X 100).

Inset: $\quad$ Degenerated villi (arrow) with and necrotic tissue (Ne) in the lumen (X400).

E) (GIII) showing complete loss of normal architecture of ileum with necrosis and degeneration of all layers (arrows), remains of necrotized tissue $(\mathrm{Ne})$ and villi $(\mathrm{V})$ in lumen. Dilated blood vessel is seen (Bv) (X100). 

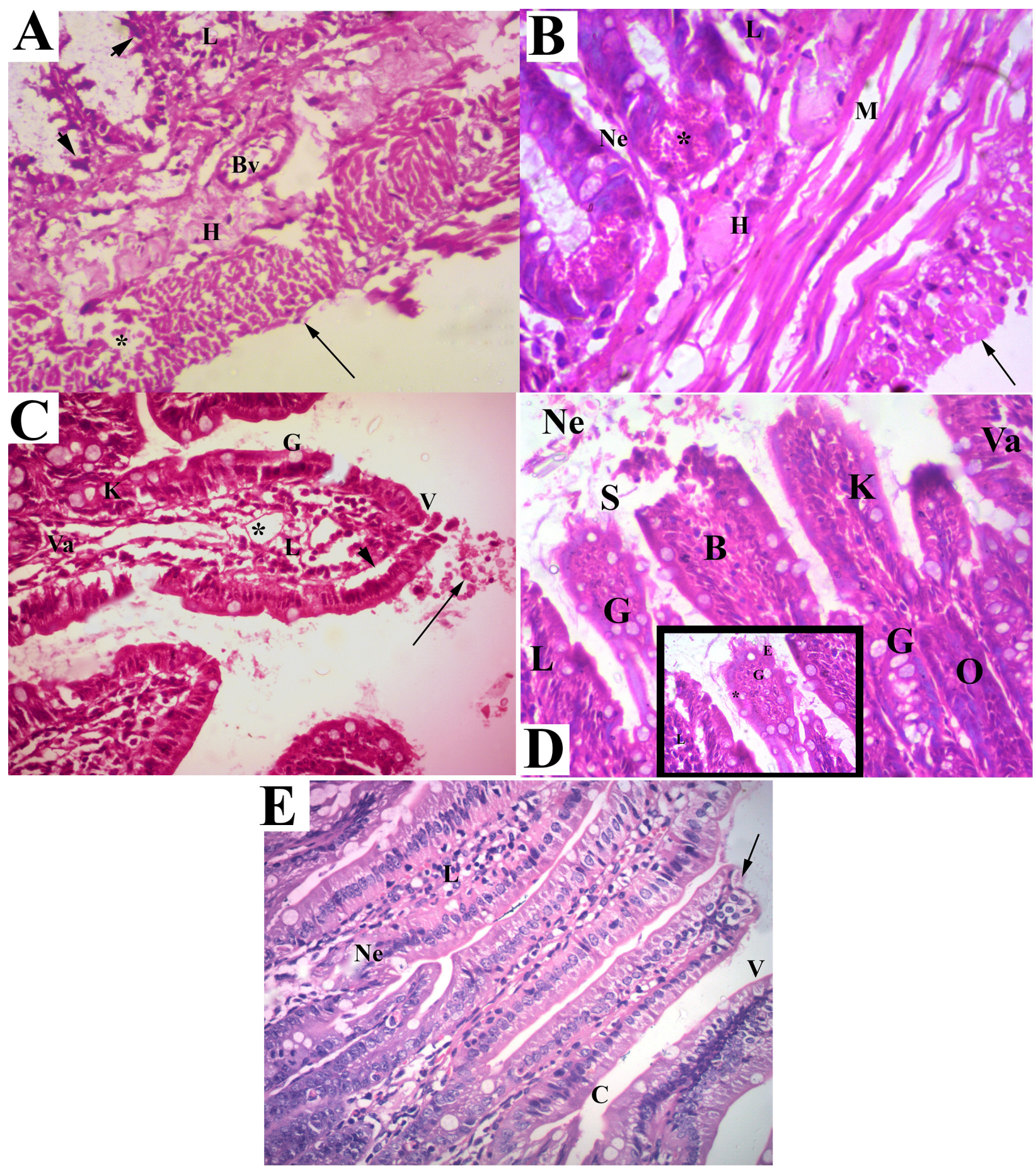

Fig 2: Photomicrograph of $\mathrm{Hx} \& \mathrm{E}$ stained sections in rat ileum from:

A) (GIII) showing complete loss of cells covering villi \&lining crypts (arrow head), lymphocytic infiltration (L), hyalinization (H) of submucosa with dilated congested blood vessels (Bv). Necrosis in muscle layer with vacuolation $\left(^{*}\right)$ and partially lost serosa (arrow) (X200). B) (GIII) showing hyalinization (H) of submucosa, necrosis \& vacuolation in muscle layer $(\mathrm{M})$, necrosis in basal cells $(\mathrm{Ne})$ lining crypts. Hemorrhage $\left(^{*}\right)$ and lymphocytic infiltration (L) and complete loss of serosa (arrow) are seen (X400).

C) (G III) showing villi (V) with shedding of cells in the lumen (arrow), lymphocytic infiltration (L) and dilatation of central lacteals $(*)$ of C.T core of villi. Vacuolation (Va) in some cells and pyknotic nuclei (K) of other cells are seen. Cells are separated from underlying CT (arrow head)

Notice: apparent few numbers \& small sizes of goblets cells $(\mathrm{G}) \mathrm{X} 400$.

D) (GIII) showing broadening villi (B) with sloughed parts of covering epithelium (S), necrotized tissue (Ne) in lumen and obliterated lumen $(\mathrm{O})$ of some crypts. Lymphocytic infiltration (L), vacuolation (Va) in some cells and pyknotic nuclei (K)of other cells and vacuolated goblet cells $(\mathrm{G})$ are seen $(\mathrm{X} 200)$.

Inset: Necrotized columnar absorptive cells (E) cells, disorganized vacuolated goblet cell (G) and some apparently small sized goblet cells $(*)(\mathrm{X} 400)$.

E) (GIV) showing nearly normal villi (V) and crypts (C) with shedding of parts of epithelium (arrow), degeneration of some cells (Ne) and some lymphocytic infiltration (L) (X400). 


\section{Mallory staining:}

Mallory stained sections of (GI) and (GII) revealed mild normal deposition of collagen fibers in mucosa and submucosa (Fig 3A \& 3B). In (GIII) there was excessive deposition of collagen fibers between damaged crypts, in
C.T core of damaged villi and under covering epithelium and in submucosa (Fig 3C). In (GIV) moderate deposition of collagen fibers in core of villi, between crypt and submucosa was detected (Fig 3D).

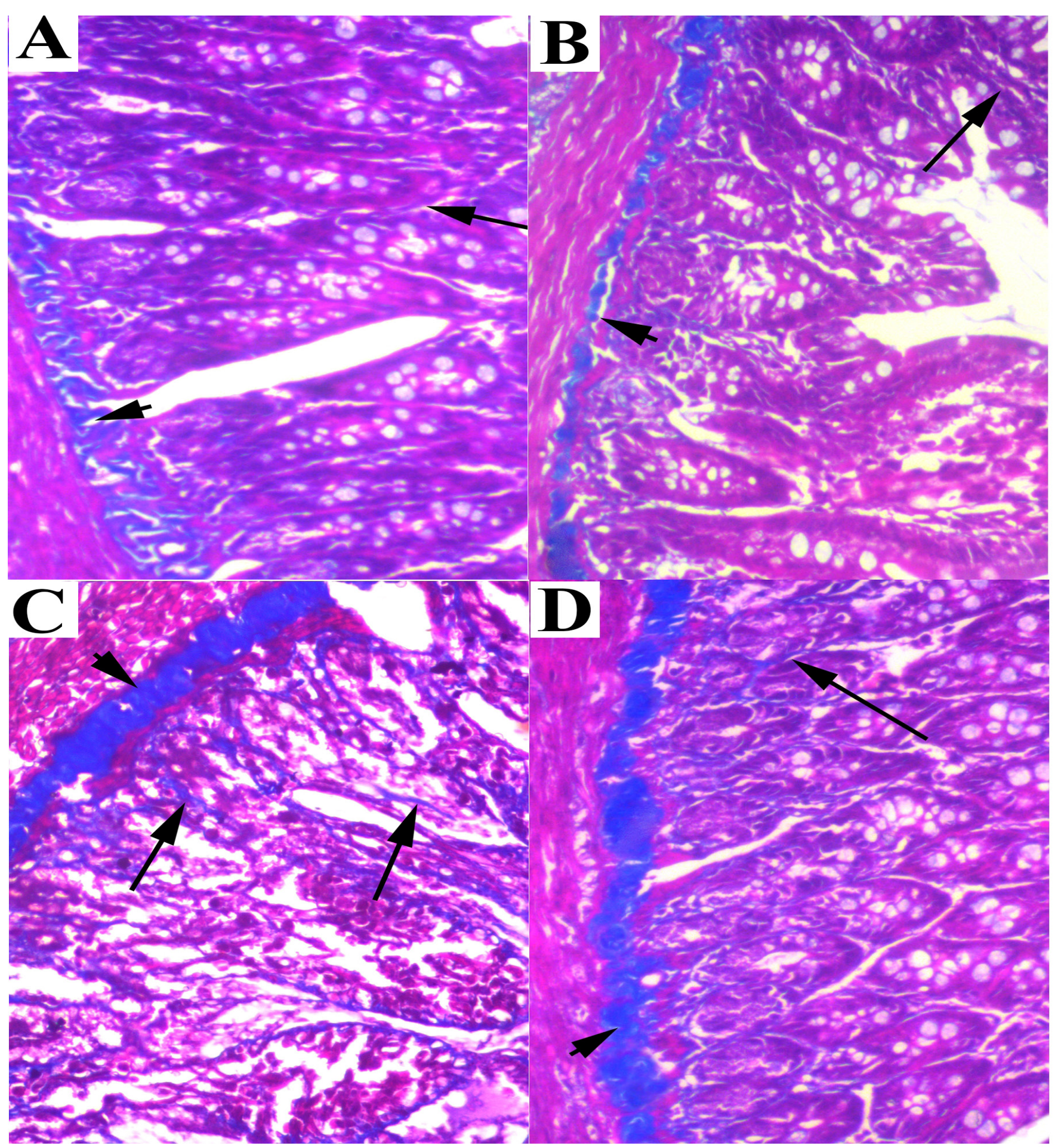

Fig 3: Photomicrograph of Mallory Trichrome stained sections (X400) in rat ileum from:

A) control showing mild normal deposition of collagen fibers in mucosa (arrow) and submucosa (arrow head).

B) (GII) showing mild normal deposition of collagen fibers in mucosa (arrow) and submucosa (arrow head).

C) (GIII) showing excessive deposition of collagen fibers between damaged crypts and in C.T villi ( arrow) and in submucosa (arrow head).

D) (GIV) showing moderate deposition of collagen fibers in mucosa (arrow) and submucosa (arrow head). 


\section{$\square \quad$ Alcain blue staining:}

Alcain blue stained sections of (GI) and (GII) revealed apparently strong intensity of acidic mucous granules and normal distribution of goblet cells (Figs 4A \& 4B). Sections of (GIII) showed apparently weak intensity of acidic mucous (Fig 4C). Sections of (GIV) revealed strong intensity but still weak intensity in some areas were seen (Fig 4D).

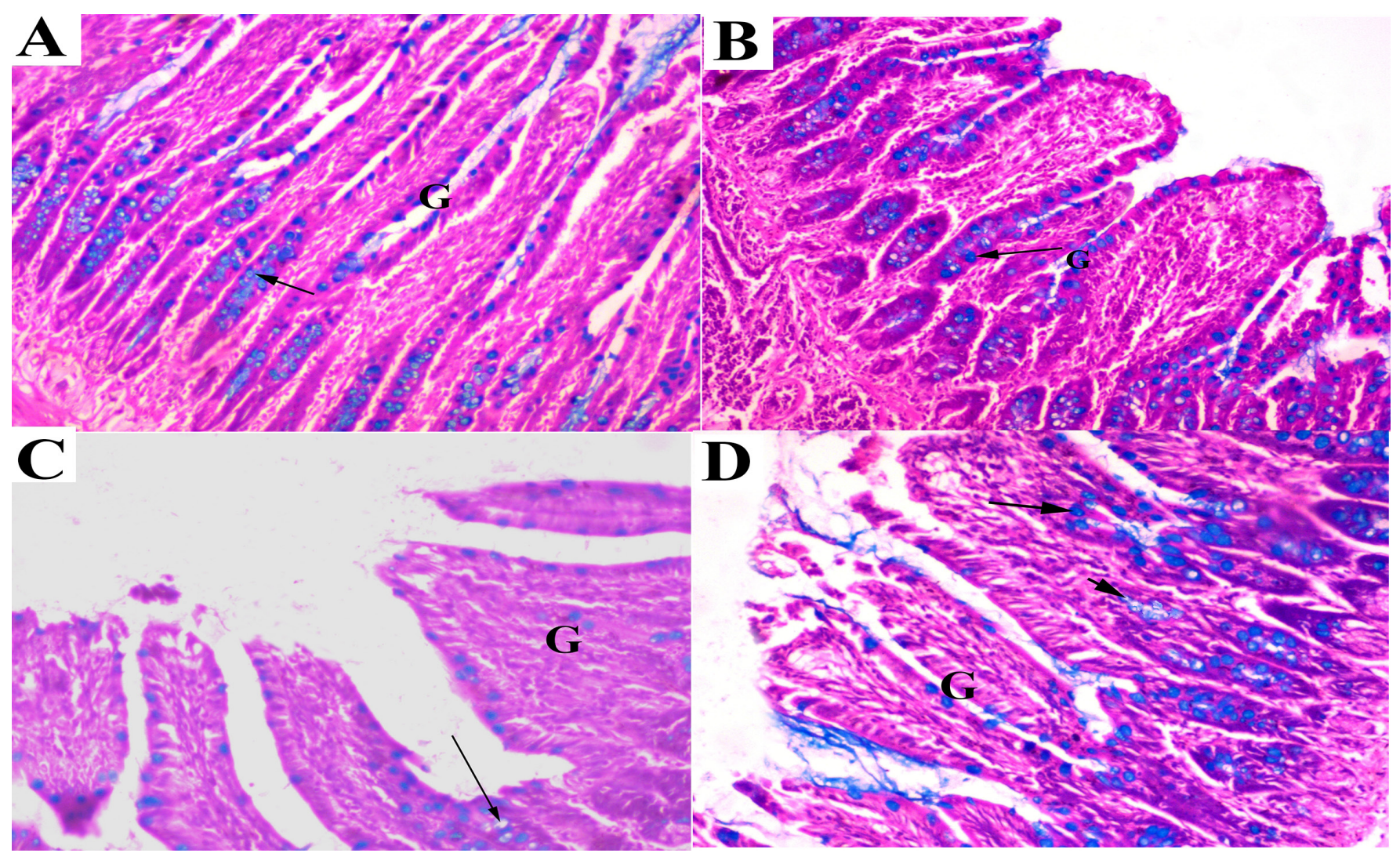

Fig 4: Photomicrograph of Alcain blue stained sections (X400) in rat ileum from:

A (GI) showing strong intensity (arrow) of acidic mucous granules, normal distribution of goblet cells (G).

B) (GII) showing strong intensity (arrow) of acidic mucous granules, normal distribution of goblet cells $(\mathrm{G})$.

C) (GIII) showing weak intensity of acidic mucous (arrow) with scanty distribution of goblet cells $(\mathrm{G})$ in $\mathrm{C}$. T core of villi and lumen of crypts.

D) (GIV) showing strong intensity of acidic mucus (arrow) but still weak intensity (arrow head) in some areas are seen. Distribution of goblet cells $(\mathrm{G})$ is nearly normal in villi and crypts.

\section{Electron Microscopic results:}

E.M results of ileum of (GI) revealed columnar absorptive epithelium cells with apical microvilli, terminal web and junctional complex. Numerous mitochondria, RER cisternae and oval heterochromatic nuclei were also seen. Pale $M$ cells were seen between absorptive cells and covered by microvilli from adjacent absorptive cells. Goblet cells had cylindrical basal part with oval nuclei, RER cisternae and wide apical distended part filled with mucous granules (Figs 5A - 5C). Paneth cells with RER cisternae, secretory granules with large protein core and oval nucleus were seen (Fig 5D). Enteroendocrine cells with characteristic basal granules near corium were noticed (Fig 5E) E.M. findings of (GII) were the same as those of control (Fig 5 F).

E M results of (GIII) showed damaged absorptive cells with irregular hyperchromatic shrunken nuclei. There was partial or complete loss of apical microvilli. Irregular junction complexes were revealed between damaged cells. Their cytoplasm showed destructed mitochondria and marked vacuolation. Some cells showed marked degeneration and damaged organelles in intestinal lumen (Fig 6A \& 6B). Some goblet cells showed decreased or complete depletion of their mucous granules while others showed complete destruction (Fig 6C \& 6D). Paneth cells revealed small irregular hyperchromatic nuclei, few RER cisternae and damaged secretory granules. Excessive collagen fibers were seen in corium (Fig 7A). Basal irregular enteroendocrine cell with apparently decreased secretory granules near corium with marked collagen were noticed (Fig7B). C.T. corium revealed eosinophil, lymphocyte, fibroblast and mast cell infiltration. (Fig 7C).

E M findings of (GIV) revealed restoration of most cells to nearly normal picture, but still there were some destructed mitochondria with mild vacuolation and cellular infiltration (Figs 8A-8D). 

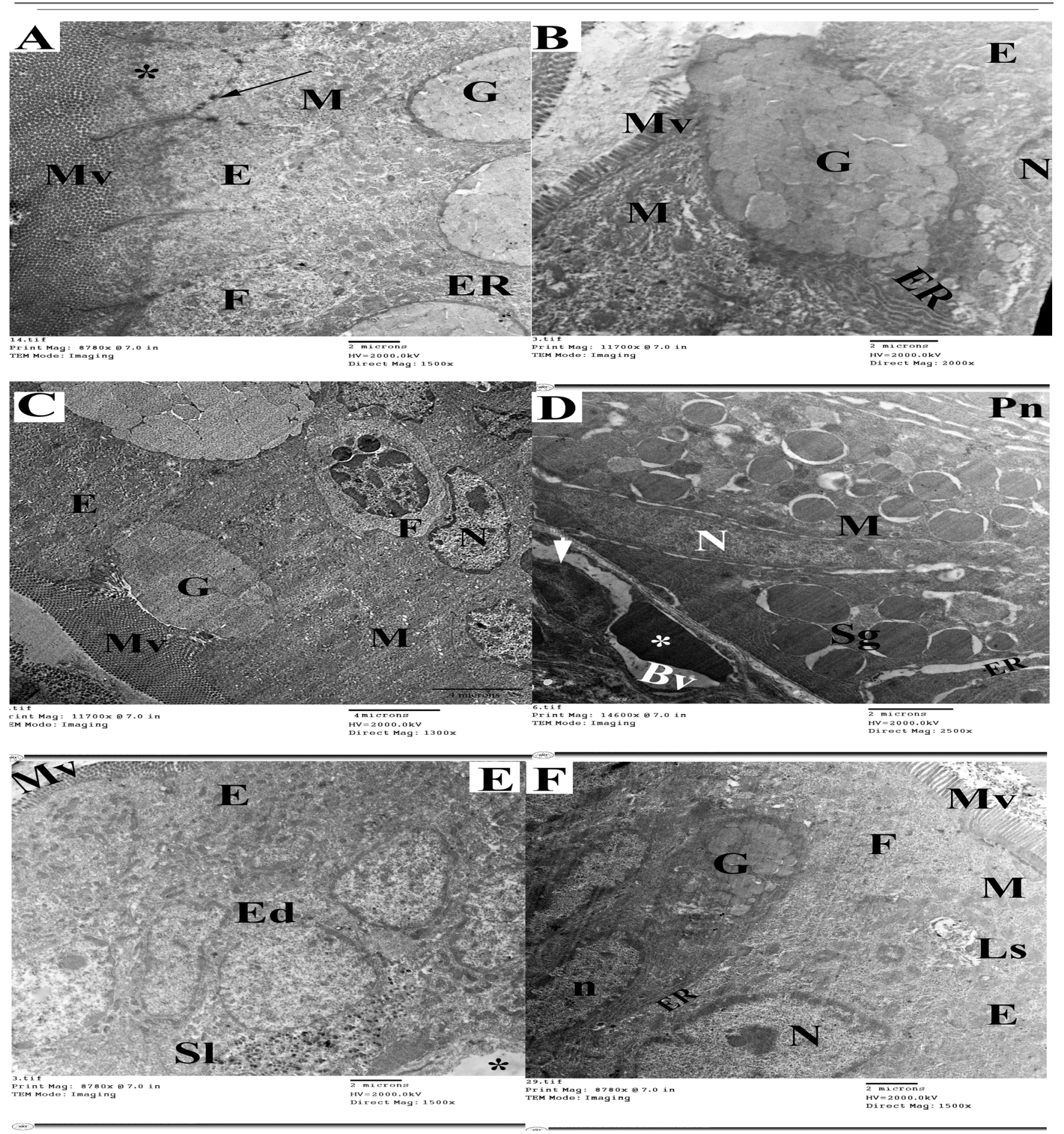

Fig 5: Electron photomicrographs in rat ileum from:

A) (GI) showing multiple columnar absorptive cells (E) with apical microvilli (Mv), junction complex's (arrow) between the cells, apical terminal web (*), numerous mitochondria (M) and RER cisterna (ER). Pale superficial microfolded M cell (F) covered by microvilli of adjacent columnar absorptive cells (E) cells is noticed. Multiple goblet cells $(\mathrm{G})$ distended with mucous granules appear between columnar absorptive cell.

$(\mathrm{X} 1500)$

B) (GI) showing columnar absorptive cells (E) with apical microvilli (Mv), numerous mitochondria (M), small part of nucleus (N). goblet cell $(\mathrm{G})$ with basal RER cisternae (ER) and wide apical part distended with mucous granules is seen.

(X2000)

C) (GI) of ileum showing columnar absorptive cells (E) with apical microvilli (Mv), numerous mitochondria (M) and heterochromatic nuclei $(\mathrm{N})$ Transverse section of Pale microfolded cell $(\mathrm{F})$ between columnar absorptive cells (E) cells. Goblet cell (G) is seen. (X1300) D) (GI) showing Paneth $(\mathrm{Pn})$ cells with RER cisternae (ER), secretory granules with large protein core (Sg), mitochondria $(\mathrm{M})$ and elongated nucleus $(\mathrm{N})$. Notice: blood vessel $(\mathrm{Bv})$ with RB C $(*)$ and lining endothelial cell (arrow head).

(X2500)

E) (GI) showing enteroendocrine cell (Ed) with characteristic basal granules (Sl) near corium $(*)$. Simple columnar cells (E) with its microvilli (Mv) are seen.

(X1500)

F) (GII) showing columnar absorptive cells (E) with apical microvilli (Mv), mitochondria (M), secondary lysosomes (Ls) and oval nuclei (N). Goblet cell (G) with basal oval nucleus(n), RER cisterna (ER) and apical mucous granules. 


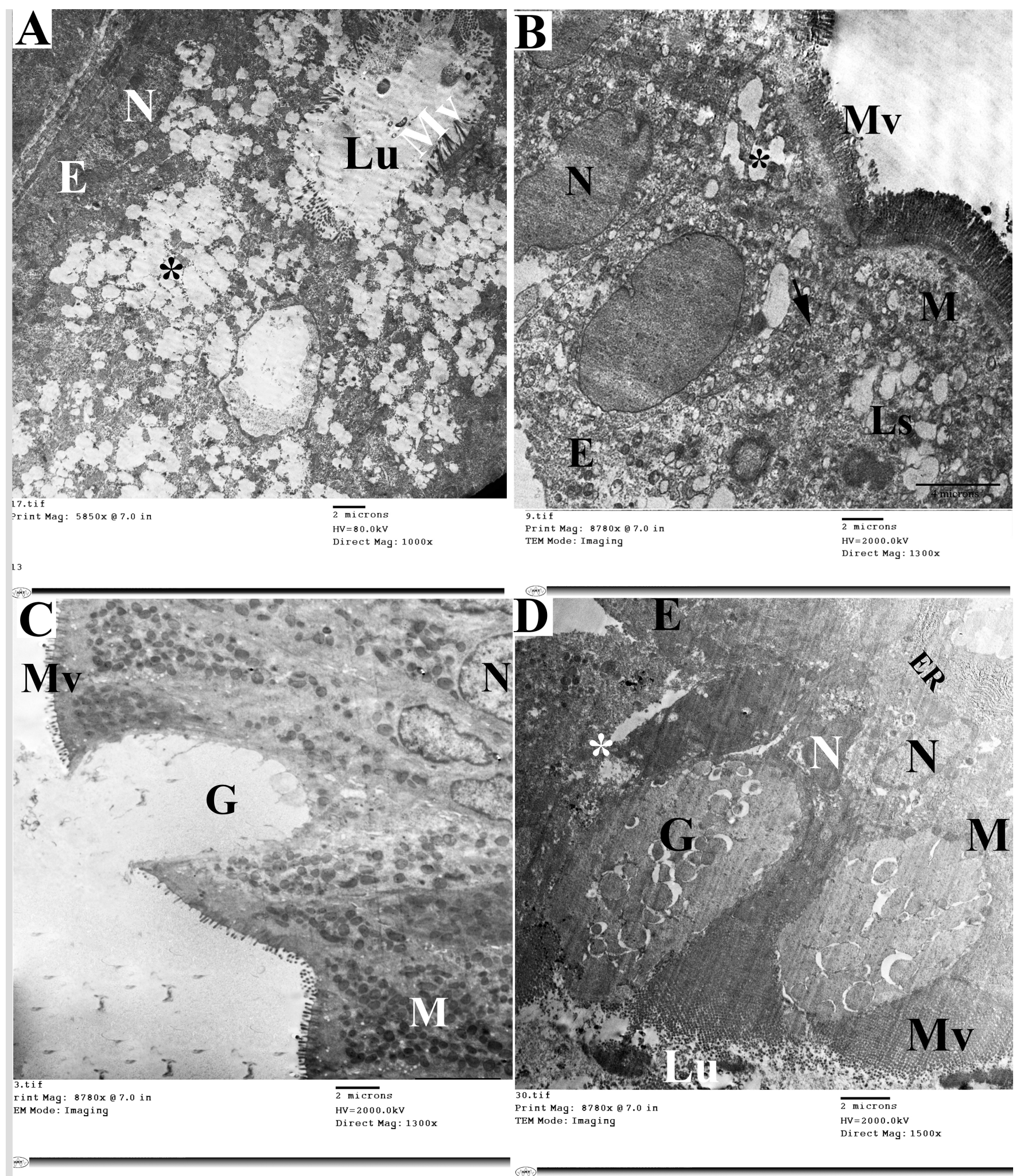

Fig 6: Electron photomicrographs in rat ileum from:

A) (GIII) showing ileum lumen (Lu) with destructed microvilli (Mv), marked vacuolation $(*)$ of cytoplasm, remnant of columnar absorptive cells $(\mathrm{E})$ with elongated nucleus $(\mathrm{N})$.

(X1000)

B) (GIII) showing damaged columnar absorptive cells (E) with damaged apical microvilli (Mv), damaged mitochondria (M), lysosomes $(\mathrm{Ls})$, shrunken heterochromatic nuclei $(\mathrm{N})$, and areas of necrosis and vacuolation $(*)$. Notice: interrupted intercellular junction complex (short arrow).

(X1300)

C) (GIII) showing lost Goblet cell (G), damaged apical microvilli (Mv), numerous shrunken mitochondria (M) and shrunken heterochromatic nuclei $(\mathrm{N})$. D) (GIII) showing columnar absorptive cells (E) with damaged apical microvilli (Mv), damaged mitochondria (M), distorted RER (ER) and shrunken hyperchromatic nuclei $(\mathrm{N})$, necrotic tissue in the lumen $(\mathrm{Lu})$ and areas of necrosis and vacuolation $(*)$. Notice: Goblet cells $(\mathrm{G})$ with heterogenous mucous granules.

(X1500) 

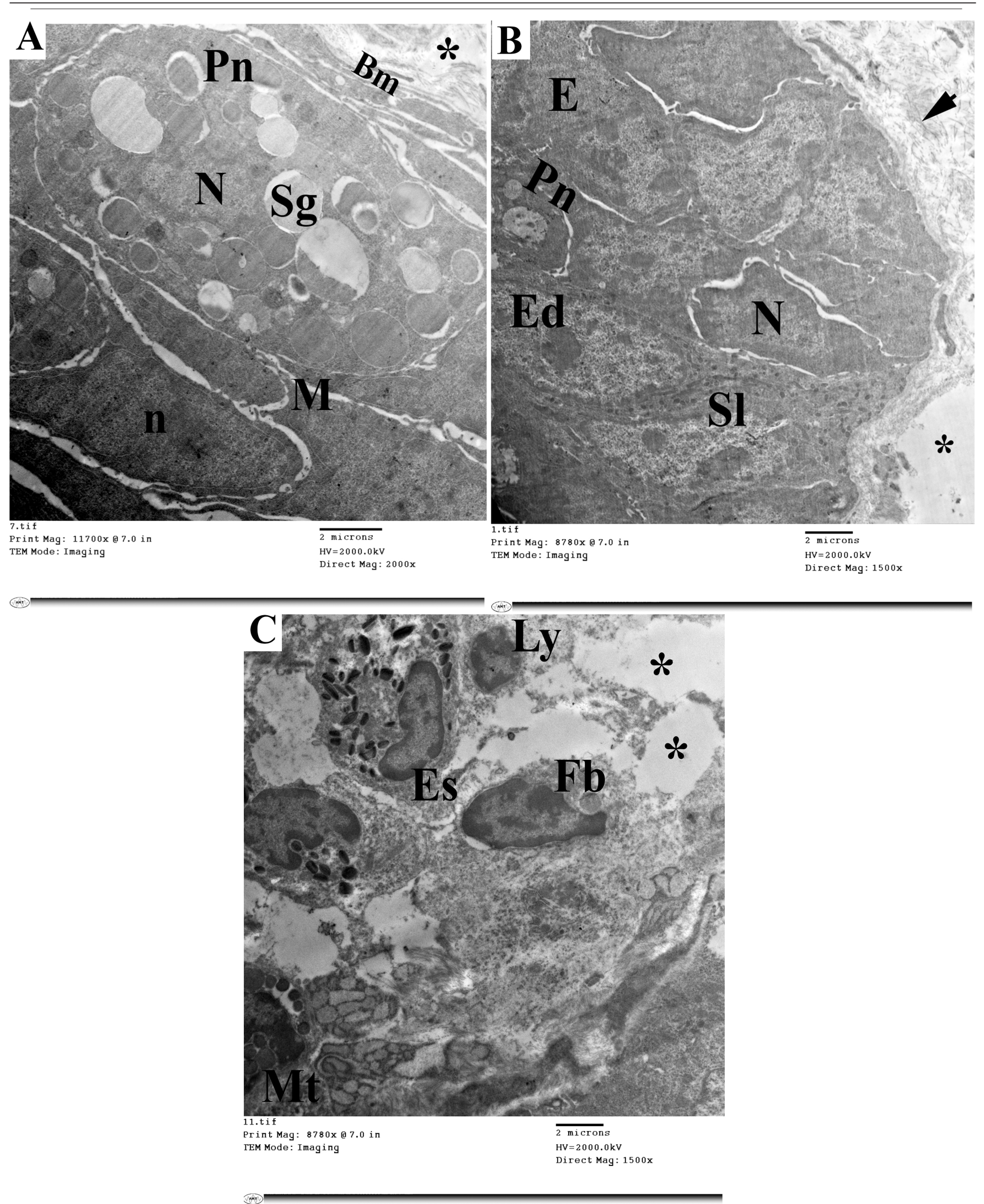

Fig 7: Electron photomicrographs in rat ileum from:

A) (GIII) showing Paneth cell $(\mathrm{Pn})$ resting on thick basement membrane $(\mathrm{Bm})$ with many disrupted \& empty secretory granules $(\mathrm{Sg})$, small irregular hyperchromatic nucleus $(\mathrm{N})$ and damaged mitochondria $(\mathrm{M})$. Notice: excessive collagen fibers $(*)$ in C.T. corium. (X2000) B) (GIII) showing basal irregular enteroendocrine cell (Ed) with apparently decreased secretory granules $(\mathrm{Sl})$ near corium $(*)$ with marked collagen (short arrow). Irregular Paneth cell (Pn) and pyknotic columnar cells (E) with heterochromatic nuclei (N) are seen. (X1500) C) (GIII) showing C.T. corium contain eosinophil (Es)with its characteristic granules, mast cell (Mt) with rounded granules, lymphocyte $(\mathrm{Ly})$, fibroblast $(\mathrm{Fb})$ and vacuolation $(*)$.

(X1500) 

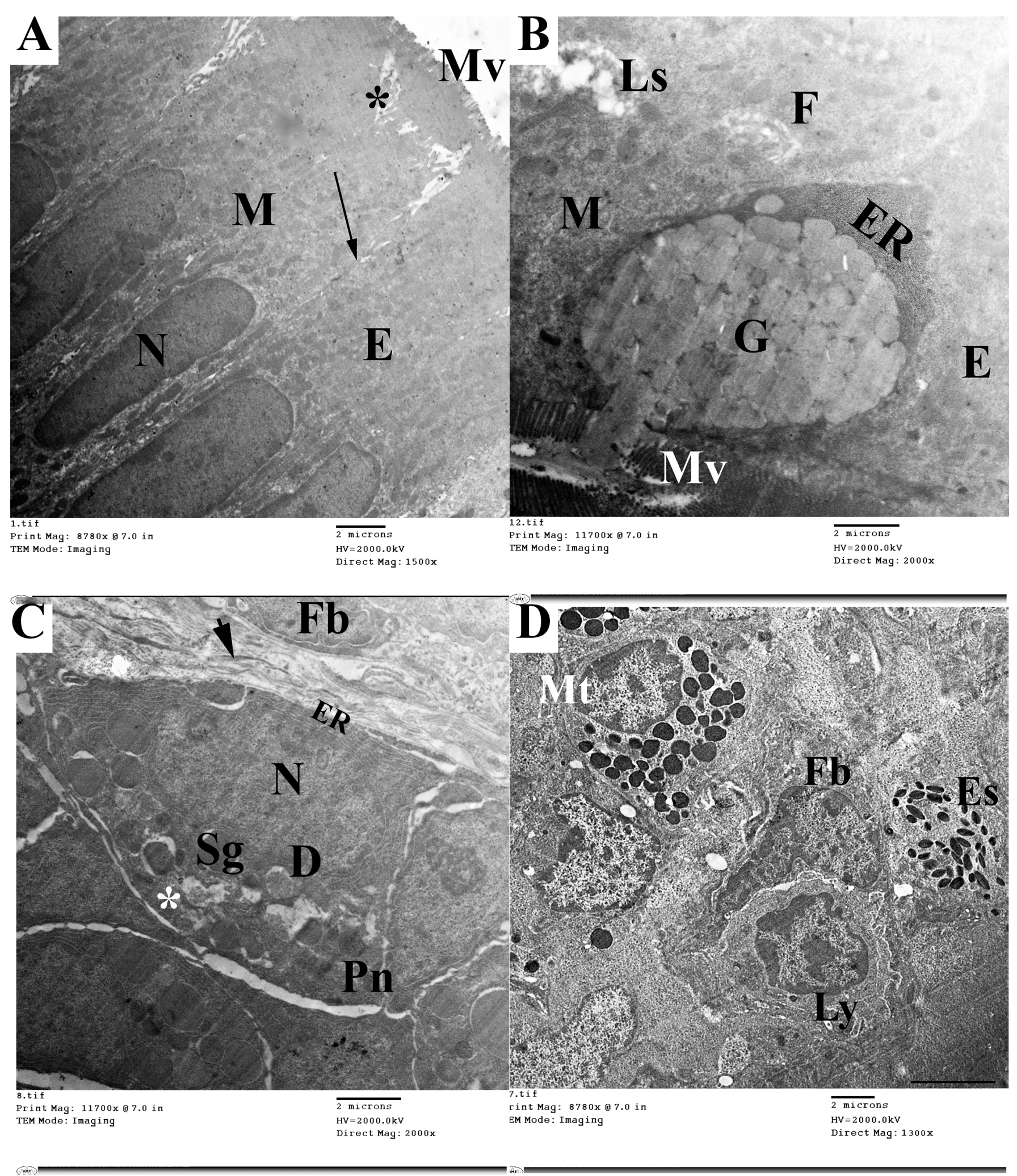

Fig 8: Electron photomicrographs in rat ileum from:

A) (GIV) showing nearly normal columnar absorptive cells (E) with less prominent microvilli (Mv), small areas of vacuolation (*), mitochondria (M), nearly normal euchromatic nuclei (N). Notice: apparently normal intercellular junction (arrow).

(X1500)

B) (GIV) showing columnar absorptive cells (E) contains mitochondria (M), secondary lysosome (Ls) and pale microfolded M cell (F). Notice: apparently normal Goblet cell (G) with RER(ER) pouring mucous secretion to lumen.

(X2000)

C) (GIV) showing apparently normal Paneth cell (Pn) with euchromatic nucleus (N), RER (RE) cisternae some normal secretory granules ( $\mathrm{Sg}$ ) other degenerated (D) and some areas of vacuolation $(*)$ Notice: collagen fibers (short arrow) \& fibroblast (Fb) in C.T. corium. D) (GIV) showing C.T. corium of ileum still containing inflammatory (X2000) mast cell (Mt), fibroblast $(\mathrm{Fb})$ and lymphocyte (Ly). 


\section{PCNA immunohistochemical staining:}

PCNA stained sections of (GI and GII) showed strong positive PCNA staining (fig 9A \& 9B). Weak positive PCNA staining revealed in (GIII) (fig 9C). There was moderate positive PCNA staining in (GIV) (fig 9D).

\section{$\square \quad$ Morphometric analysis:}

The mean of villi length, crypts depth, epithelium height, number of goblet cells, number of PCNA-positive cells, optical density of Alcian Blue showed significant changes in $(\mathrm{G}$ III) as compared to control $(p<0.05)$ (Table 1) (Figs 10 and 11)

(G IV) showed non-significant changes in all these parameters as compared to control group $(P>0.05)$ (Table 1) (Figs 10 and11).

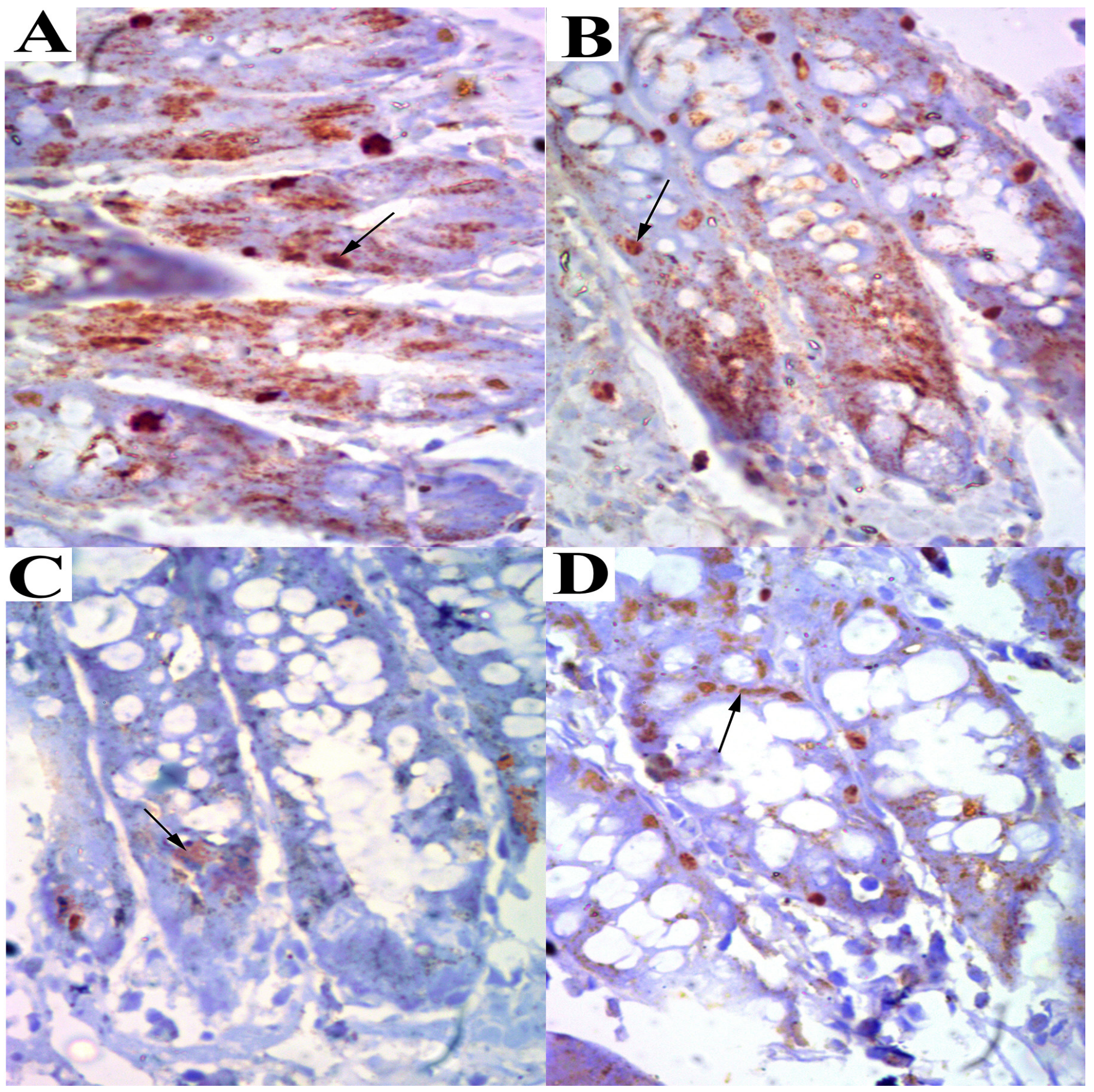

Fig 9: Photomicrograph of PCNA stained sections (X400) in rat ileum from:

A) (G1) showing strong positive PCNA reaction in crypts cells (arrow)

B) (GII) showing strong positive PCNA reaction in crypts cells (arrow)

C) (GIII) showing weak positive PCNA reaction in crypts cells (arrow)

D) (GIV) showing moderate positive PCNA reaction in crypts cells(arrow) 
Table 1: Morphometric results: Villi length, Crypt depth,Epithelium height,Number of goblet cells,Mean optical density of Alcian blue and Mean number of PCNA.

\begin{tabular}{|c|c|c|c|c|}
\hline & GI & GII & GIII & GIV \\
\hline VILLI LENGTH $\pm \mathrm{SD}(\mu \mathrm{m})$ & $0.728 \pm 0.07$ & $0.698 \pm 0.05$ & $0.262 \pm 0.08^{*}$ & $0.456 \pm 0.03$ \\
\hline $\mathrm{CRYPT} \mathrm{DEPTH} \pm \mathrm{SD}(\mu \mathrm{m})$ & $0.358 \pm 0.095$ & $0.349 \pm 0.08$ & $0.142 \pm 0.01^{*}$ & $0.299 \pm 0.97$ \\
\hline EPITHELIUM HEIGHT \pm SD $(\mu \mathrm{m})$ & $0.046 \pm 0.008$ & $0.044 \pm 0.006$ & $0.027 \pm 0.007^{*}$ & $0.039 \pm 0.008$ \\
\hline NUMBER OF GOBLET CELLS / HPF \pm SD & $45.2 \pm 8.22$ & $44.6 \pm 11.06$ & $14.9 \pm 1.11^{*}$ & $42.1 \pm 7.82$ \\
\hline $\begin{array}{l}\text { MEAN OPTICAL DENSITY OF ALCIAN } \\
\text { BLUE+VE REACTION } \pm \text { SD }\end{array}$ & $0.92 \pm 0.04$ & $0.91 \pm 0.08$ & $0.67 \pm 0.01^{*}$ & $0.82 \pm 0.04$ \\
\hline $\begin{array}{l}\text { MEAN NUMBER OF PCNA + VE CELLS / } \\
\mathrm{HPF} \pm \mathrm{SD}\end{array}$ & $39.2 \pm 7.63$ & $37.8 \pm 4.42$ & $20 \pm 3.84^{*}$ & $30 \pm 8.83$ \\
\hline
\end{tabular}

*significant as compared to group I $(p<0.05)$

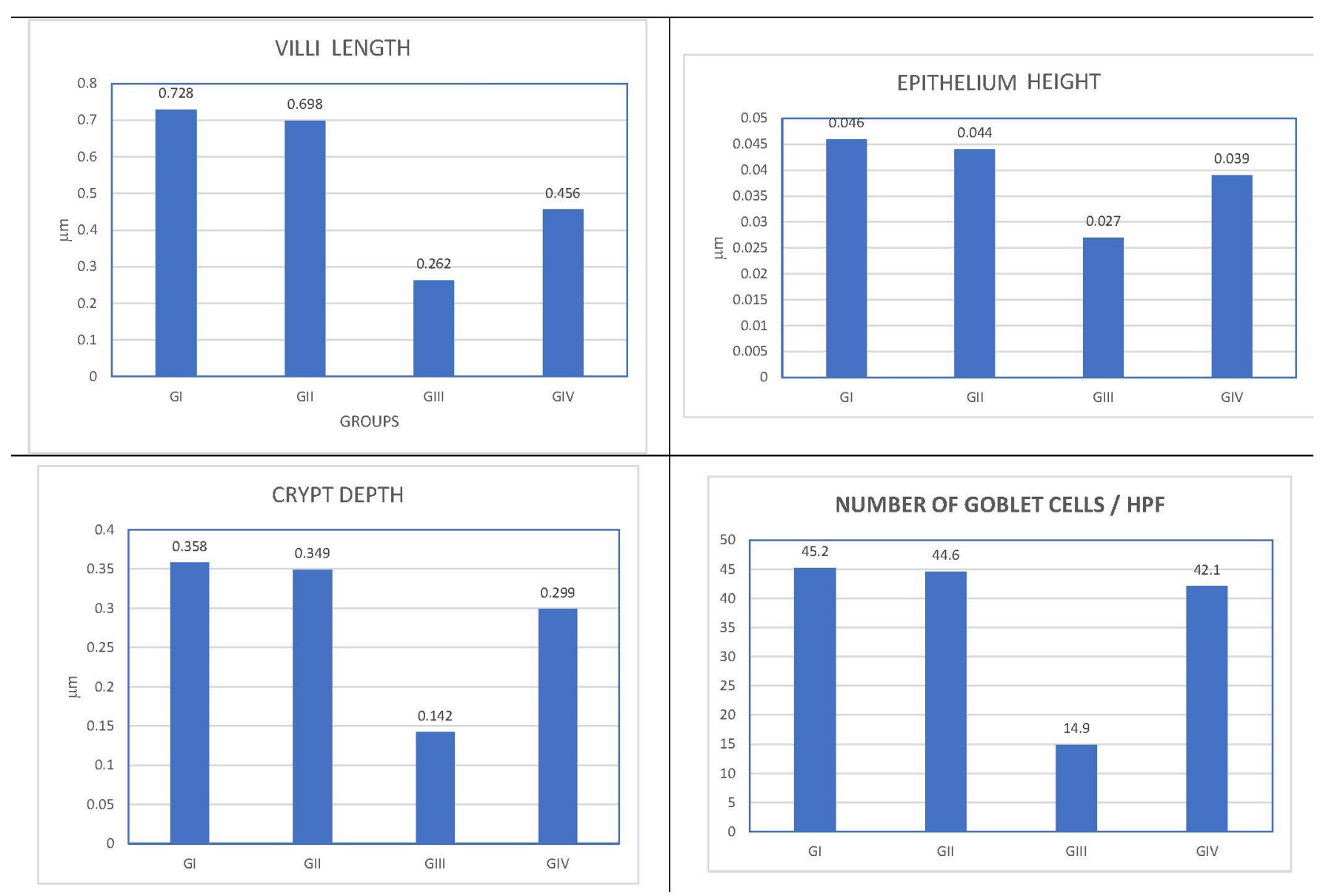

Fig 10: Bars chart showing Villi length, Crypt depth,Epithelium height and Number of goblet cells. 

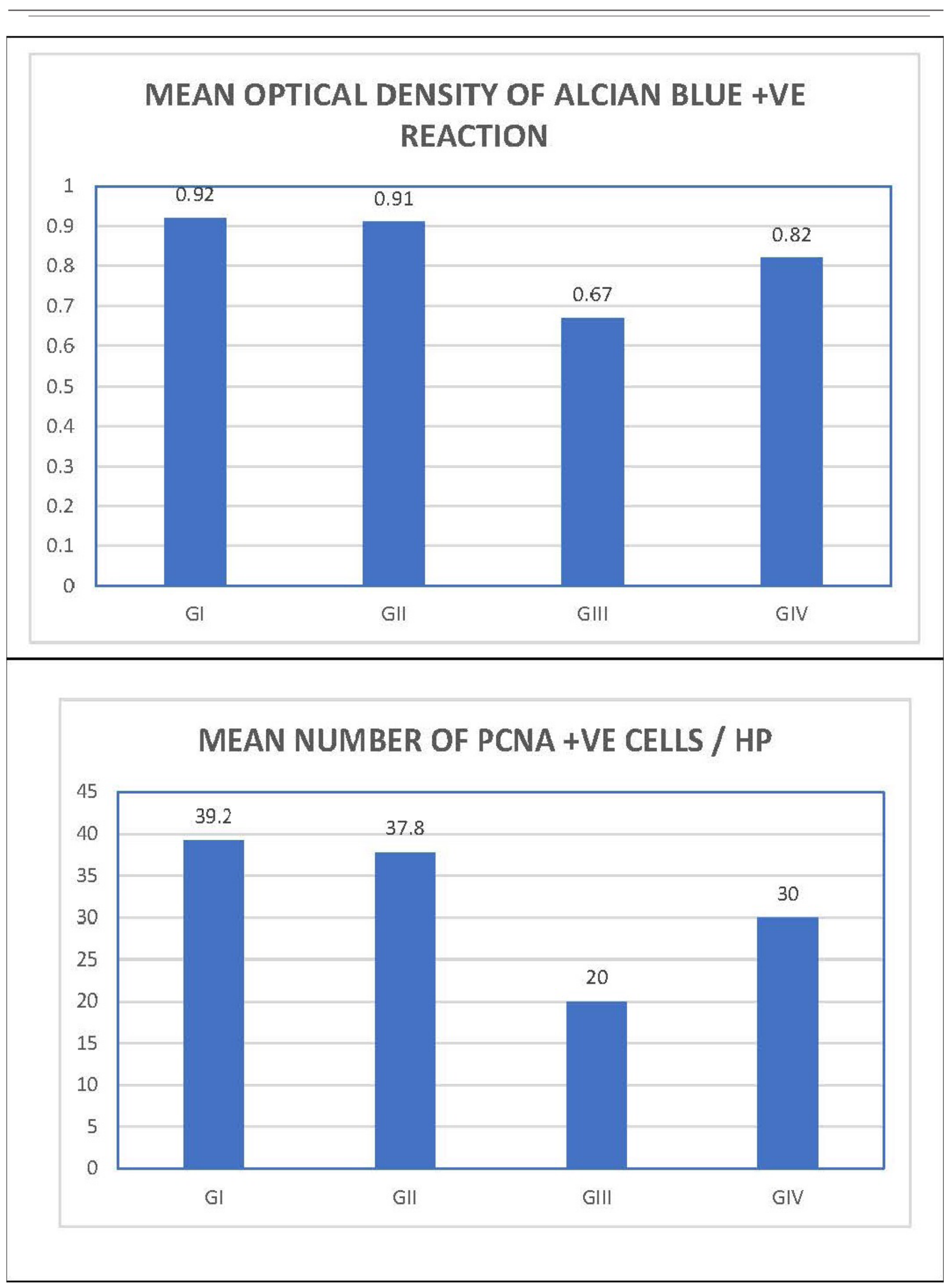

Fig 11: Bars chart showing: Mean optical density of Alcian blue and Mean number of PCNA +ve cells. 


\section{Aflatoxin detection:}

Aflatoxin B1 concentration was detected using HPLC. Fig (12) showed the curve of the extracted aflatoxins from the toxigenic A. Flavus. The concentration was calculated through the comparison between the area under the curve of the standard and the sample. The concentration of AFB1 from the extracted samples was $19.8 \mu \mathrm{g} / 100 \mathrm{ml}$.

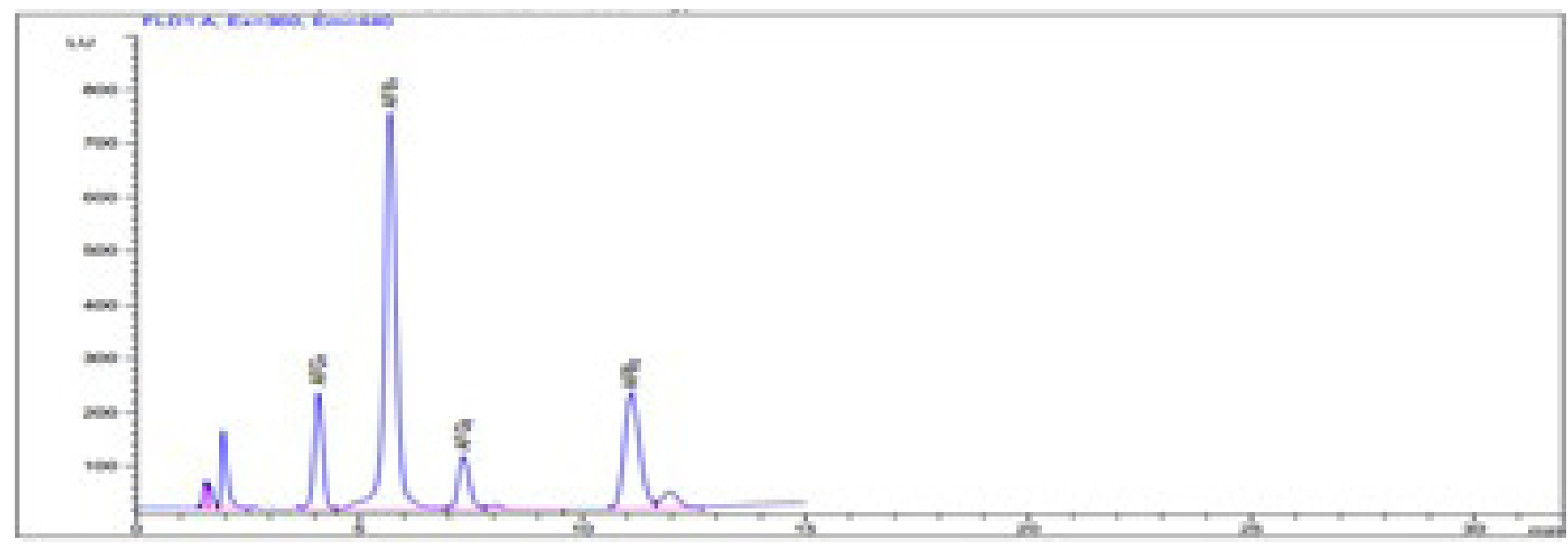

$Q 1$

Fig 12: The curve of the extracted aflatoxins from the toxigenic A.

\section{DISCUSSION}

Aflatoxins (AFs) are secondary metabolites of some molds that grow on food and crops. Consuming AFs contaminated food result in many health problems. AFs may be the cause of immunosuppression, infections and elevated death rates. AFB1 is the most dangerous of AFs because it is highly teratogenic, mutagenic and carcinogenic ${ }^{[17]}$.

Small intestine is an essential segment not only for absorption function, but also it is the gate that control the entry of contaminants and antigens from the lumen to the internal body. Ileum has special importance because of its vital role in GIT immunity ${ }^{[18]}$.

Histological results of Aflatoxin group (GIII) showed loss of normal organization, some villi with shedding of its covering epithelium, others show broadening due to asymmetrical loss of epithelium $^{[18]}$.

The degenerative, necrotic and pyknotic changes in cells in (GIII) can be referred to oxidative stress of aflatoxins, that result in destroying of essential macromolecules of the cells (lipids, DNA and proteins) ${ }^{[18]}$. Moreover, another cause for degeneration, is calcium accumulation in the cells in aflatoxicosis ${ }^{[19]}$

The villus length, crypt depth, and epithelium height are important indicators of the intestinal health. Comparing with control group, all pervious parameters show statistically significant differences, confirming that AFB1 decrease the ileum surface area for absorption ${ }^{[20]}$.
Abdel Mohsen et al., ${ }^{[2]]}$ explain these morphometric changes (decreased villi length and epithelium height and increased depth of crypts) by shedding, loss of epithelium in villi \& crypts and reduced cell division in the ileum mucosa in Aflatoxin group. Statistically significant reduction in the mean number of goblet cells in GIII compared to control group is accompanied with some compensatory increased size and vacuolation. This finding is in accordance with other authors ${ }^{[21]}$.

Ulceration of the mucosa and damaging of both villi and crypts due to overproduction of nitric oxide (NO) after lipid peroxidation can be the cause of decreased goblet cells numbers ${ }^{[22]}$.

Hemorrhage is seen in bases of crypts and surrounding C.T., this is in harmonization with Grozeva et al., ${ }^{[23]}$ who found that AFB1 cause generalized hyperemia.

Also, hemorrhage may be referred to coagulation failure due to disorders in coagulation factors as prothrombin, factor VII and X following aflatoxicosis ${ }^{[24]}$.

Dilatated congested blood vessels in (GIII) may be explained by endothelial relaxing factors formed by oxidative stress $^{[25]}$.

C.T. core of villi of G III show heavy lymphocytic infiltration and dilatation of central lacteals. Marked increase in size of payer's patches and lymphatic nodules also is detected. It may be explained by affection of cellular immunity ${ }^{[26]}$. 
Also, it is found that Aflatoxin produces reactive oxygen species (ROS), which induce inflammatory process by formation of Tumor necrosis factor (TNF- $\alpha$ ) and cytokines that attract leukocytes and other inflammatory cells into lesion site as a protection mechanism to eliminate injured tissue. This is confirmed by E.M. findings in GIII ${ }^{[27]}$.

In GIII, there are hyalinization, thinning and degeneration in muscle layer and complete destruction of all layers in some parts of ileum. This can be explained by that, Aflatoxins works as suppressor of protein formation due to its fusion with nucleic acid. So, AFs have damaging effects on cells specially ileum because its high protein turnover ${ }^{[28]}$

Furthermore, collection of reactive free radicals releases lysosomal enzymes into the cytosol which lead to oxidation and lysis of the protein ${ }^{[27]}$.

By using transmission electron microscope, in GIII damaged absorptive columnar cells and $\mathrm{M}$ cells (which can be considered differentiated form of absorptive columnar cells ${ }^{[29]}$ ) show shrinkage of their nuclei, interrupted intracellular junctions' complexes, loss of terminal webs and lost damaged microvilli ${ }^{[18]}$

Some goblet cells with shrunken nuclei show decrease or complete depletion of mucous granules. other goblet cells show complete destruction, Paneth cells reveal irregular nuclei and damaged mitochondria with partially depleted secretory granules ${ }^{[19]}$.

All cells in the ileum were affected, this could be explained by two different theories. First, aflatoxin transforms into damaging AFB-8,9 epoxide product. Second, aflatoxin produces ROS like hydrogen peroxide (H2O2), hydroxyl radical and superoxide anion which attack soluble cell structures as cell membranes and DNA leading cell damage and death.

Moreover, it is found that aflatoxin caused suppression of antioxidant enzymes activities such as superoxide dismutase, catalase, and glutathione peroxidase As well as, it suppresses the activities of nonenzymatic antioxidants such as total ascorbic acid and Alpha-tocopherol ${ }^{[30]}$.

Mitochondria showed lysis of its contents in the AFB1 group. Previous studies prove that mitochondrial damages are caused by the interaction of AFB1 metabolite and oxidative ROS with mitochondrial proteins and nucleic acids $^{[5]}$. That leads to mitochondrial dysfunction and reducing adenosine triphosphate (ATP) generation ${ }^{[18]}$.

C.T core of villi and lamina propria revealed infiltration of eosinophil, mast cell, lymphocytes and fibroblasts, this is in harmony with Colakoglu and Donmez ${ }^{[31]}$. This is explained by affection of cellular immunity. Also, the presence of many mast cells can be major indicative of the inflammatory process ${ }^{[21]}$.

By using Mallory stain, excessive collagen fibers are detected in G III, this is in harmony with Saddiq and Awedh $^{[19]}$. Elevated expression of tissue transforming growth factor beta (TGF- $\beta$ ) in ileum may be the cause as activated TGF- $\beta$ is a major mediator of fibrosis ${ }^{[19]}$.

In addition, it is proved that the inflammatory response stimulates myofibroblast which lead to out of control extracellular matrix (ECM) deposition and fibrosis ${ }^{[32]}$.

In group III, the function of goblet cells secreting acid mucin was explored by Alcian Blue staining. Goblet cells synthesize mucin that protects the mucous membrane and damage of goblet cells depress ileum immunity. AFB1 can decrease the glycogen and acid mucins production in goblet cells. So (GIII) revealed statically significant decreased expression of Alcian Blue stains ${ }^{[33]}$.

Sometimes, there was an increased mucin secretion from goblet cells as a compensatory mechanism for the lost mucus. This may explain hypertrophy of some goblet cells beside shrinkage of others that have been documented previously during aflatoxicosis ${ }^{[18]}$.

PCNA is a vital protein for DNA formation and is thus a proliferation indicator ${ }^{[34]}$. Group III reveal statically significant reduction in the mean number of PCNA +ve cells as compared to control group. This reduction can be explained by loss of epithelial cells with destruction of villi and crypts. Also, AFB1 is a strong suppressor of protein formation through its interaction with DNA and RNA. Enterocytes of ileum are highly affected because it is rapidly dividing with high protein turnover ${ }^{[33]}$.

In addition, suppression of the cell cycle in phase G2/M and decreased cell proliferation with AFB 1 are confirmed by Fouad et al. ${ }^{[20]}$ and Zhang et al., ${ }^{[33]}$.

$\mathrm{Se}$ is a fundamental component for humans and animals. It is essential for vital metabolic process, immune system and antioxidant defense mechanism ${ }^{[35]}$.

Se plays vital roles in many aspects of health protection, such as chemoprotectives, antioxidant, detoxification and anticancer effects $^{[20]}$.

H\&E stained sections of GIV (sodium selenite \& Aflatoxin group) show marked improvement and restoration to nearly normal histological picture of villi and crypts. However, shedding and degeneration of some cells of epithelium covering villi with some lymphocytic infiltration were still seen. This can be explained by Liu et al., ${ }^{[35]}$, who confirmed that Se exert protective effects on the AFB1-induced damage. It may be related with following 
causes: (1) Se can enhance immunoglobulin formation and B-cell function; (2) Se can improve conjugation \& excretion of aflatoxins (3) Se as antioxidant is connected to glutathione detoxification and scavenge superoxide anion, hydroxyl radicals and nitric oxide ${ }^{[36]}$.

Morphometric parameters, the villus length, crypt depth, and epithelium height show statically changes which correlate with histological improvements.

Electronic microscopic results of (GIV) were in agreement with light microscopic changes and show nearly normal structure but some destructed mitochondria, mild vacuolation and cellular infiltration are seen.

This improvement can be explained by reducing lipid peroxidation and reactive oxygen metabolites to maintain the integrity of membrane and macromolecules ${ }^{[37,38]}$.

Mallory stain in (GIV) reveal reduced fibrosis. This is in agreement with Zhang et al., ${ }^{[20]}$ who explain that by decreased levels of fibrotic factors as FAS, FASL, TNF- $\alpha$ and TNF-R1.

Alcian Blue staining in (GIV) show nearly normal acidic mucin intensity in goblet cells. This improvement may be referred to an enhancement in the DNA and protein content (mucoprotein) in ileum ${ }^{[39]}$

PCNA immunostaining in (GIV) revealed statically increased expression as compared to (GIII). This can be explained by the effect Se on the cell proliferation of ileum. It may be due to that, Se adjust many cell cyclerelated genes, such as PCNA, CDK1, CDK2, CDK4, cyclin B and cyclin D2 mRNA led to stimulation of cell cycle development especially in $\mathrm{G} 2 / \mathrm{M}^{[20]}$.

These changes were correlated with morphometric changes as showing statically non-significant changes of the intensity of Alcian Blue and number of goblet cells and PCNA +ve cells as compared to control.

\section{CONCLUSION}

Our results revealed that Aflatoxin B1 has destructive histopathological changes on all layers of wall of ileum of male Albino rats. High caution must be taken to avoid the potential contamination of food with aflatoxin B1.

Dietary sodium selenite can improve the ileum structure $\&$ function after impairment by AFB1.So sodium selenite is recommended specifically to susceptible categories for AFB1 contamination.

\section{CONFLICT OF INTEREST}

There are no conflicts of interest.

\section{REFERENCES}

1. Pitt JI and Miller JD. A Concise History of Mycotoxin Research. J Agric Food Chem. 2017; 65(33):7021-7033.

2. Abbasi F, Liu J, Zhang H, Shen $X$ and Luo $X$ Effects of feeding corn naturally contaminated with aflatoxin on growth performance, apparent ileal digestibility, serum hormones levels and gene expression of $\mathrm{Na}+, \mathrm{K}+$-ATPase in ducklings. Asian-Australas J Anim Sci. 2018; 31(1):91-97.

3. De Ruyck K, De Boevre M, Huybrechts I and De Saeger S. Dietary mycotoxins, co-exposure, and carcinogenesis in humans: Short review. Mutat Res Rev Mutat Res. 2015; 766:32-41.

4. Rawal S, Kim JE and Coulombe R Jr. Aflatoxin B1 in poultry: toxicology, metabolism and prevention. Res Vet Sci. 2010; 89(3):325-331.

5. Peng X, Bai S, Ding X, Zeng Q, Zhang $\mathrm{K}$ and Fang J. Pathological changes in the immune organs of broiler chickens fed on corn naturally contaminated with aflatoxins B1 and B2. Avian Pathol. 2015; 44(3):192-199.

6. Fernández-Llamosas $\mathrm{H}$, Castro L, Blázquez $\mathrm{ML}$, Díaz E and Carmona M. Biosynthesis of selenium nanoparticles by Azoarcus sp. CIB. Microb Cell Fact. 2016; 15(1):109.

7. Hoffmann PR. Selenium and asthma: a complex relationship. Allergy. 2008; 63(7):854-856.

8. Kieliszek M, Lipinski $B$ and Błażejak S Application of Sodium Selenite in the Prevention and Treatment of Cancers. Cells. 2017; 6(4):39.

9. Yousefi S, Dadgar S, Safara M and Zaini F. Aflatoxin production by Aspergillus flavus isolates from green-tiger shrimps (Penaeus semisulcatus). IRAN. J. MICROBIOL. 2009; 1(4):18-22.

10. Kalender S, Uzun FG, Demir F, Uzunhisarcikli $\mathrm{M}$ and Aslanturk A. Mercuric chloride-induced testicular toxicity in rats and the protective role of sodium selenite and vitamin E. Food Chem Toxicol. 2013; 55:456-62.

11. Kudayer AM, Alsandaqchi ATA, Saleh FM and Alwan NA. Toxic Effect of Aflatoxin B1 on Heart, Lung, and Testis of Male Albino Rats: Histopathology Study. IOP Conf. Series: Materials Science and Engineering. 2019; 571(1):012055.

12. Kiernan JA. Histological and Histochemical 
Methods - Theory and Practice. 5th ed. 2015; Scion publishing Ltd, Banbury UK, 111- 162 and 219-240.

13. Mohamed AAK, Khalil S, Nossier NS and Khalil MS. The Protective Role of Alpha-Lipoic Acid Against Doxorubicin - Induced Cardiotoxicity in Male Albino Rats (A Light and Transmission Electron Microscopy Study). Egypt. J. Histol. (2009) 32(1): 227 -234?

14. Suvarna KS, Layton C \& Bancroft JD. Bancroft's Theory and Practice of Histological Techniques, 7th Edition. 2012; Elsevier Health Science, China, 381-426.

15. Emsley R, Dunn G and White IR. Mediation and moderation of treatment effects in randomised controlled trials of complex interventions. Stat Methods Med Res. 2010; 19(3):237-270.

16. Association of Official Analytical Chemists. Official methods of analysis of A.O.A.C. International $17^{\text {th }}$ Ed. 2000, Nature Toxins, Arlington, Virginia, USA, chapter 49.

17. Liu N, Wang JQ, Liu ZY, Wang YC and Wang JP. Comparison of probiotics and clay detoxifier on the growth performance and enterotoxic markers of broilers fed diets contaminated with aflatoxin B1. The Journal of Applied Poultry Research. 2018; 27(3):341-348.

18. Wang F, Zuo Z, Chen K, Gao C, Yang Z, Zhao S, Li J, Song H, Peng X, Fang J, Cui H, Ouyang P, Zhou Y, Shu G and Jing B. Histopathological Injuries, Ultrastructural Changes, and Depressed TLR Expression in the Small Intestine of Broiler Chickens with Aflatoxin B $\square$. Toxins (Basel). 2018; 10(4).

19. Saddiq AAN and Awedh MH. Pumpkin (Cucurbita moschata) against Aspergillus flavus and aflatoxin B1 induced lung cyto-morphological damage in rats. Pak J Pharm Sci. 2019; 32(2):575-579.

20. Zhang S, Peng X, Fang J, Cui H, Zuo Z and Chen $Z$. Effects of aflatoxin B1 exposure and sodium selenite supplementation on the histology, cell proliferation, and cell cycle of jejunum in broilers. Biol Trace Elem Res. 2014; 160(1):32-40.

21. Abdel Mohsen AF, Salama NM, Rashed LA, Farag EA and Abdel Hameed AM. A Comparative Histological Study on the Effect of AdiposeDerived Stem Cells versus Their Conditioned Medium on Indomethacin Induced Enteritis in Adult Female Albino Rats. The Egyptian Journal of Histology, 2018; 41(4):503-519.

22. Zhang Y, El-Far M, Dupuy FP, Abdel-Hakeem MS, He Z, Procopio FA, Shi Y, Haddad EK, Ancuta P, Sekaly RP and Said EA. HCV RNA Activates APCs via TLR7/TLR8 While Virus Selectively Stimulates Macrophages Without Inducing Antiviral Responses. Sci Rep. 2016; 6:29447.

23. Grozeva N, Valchev I, Hristov Ts, Lazarov L and Nikolov Y. Histopathological changes in small intestines of broiler chickens with experimental aflatoxicosis. Agric. Sci. Technol.2015,7, 319323.

24. Lakkawar, AW, Chattopadhyay SK and Johri TS. Experimental aflatoxin B1 toxicosis in young rabbits - A clinical and patho-anatomical study. Slov. Vet. Res. 2004; 41(2):73-81.

25. Laaga EM and Abd Elaziz HO. Effect of aflatoxin-B1 on rat cerebellar cortex: light and electron microscopic study. The Egyptian Journal of Histology. 2013; 36(3):601-610.

26. Akinrinmade FJ, Akinrinde AS and Amid A Changes in serum cytokine levels, hepatic and intestinal morphology in aflatoxin B1-induced injury: Modulatory roles of melatonin and flavonoid-rich fractions from Chromolena odorata. Mycotoxin Res. 2016; 32:53-60.

27. Soliman GM and Tawfik SM. Histological and immunohistochemical study on the effect of aflatoxin B1 on the left ventricular muscle of adult male rabbit with reference to the protective role of melatonin. The Egyptian Journal of Histology. 2014; 37(4):655-666.

28. Kumar R and Balachandran C. Histopathological 
changes in broiler chickens fed aflatoxin and cyclopiazonic acid. Vet. Arhiv, 2009; 79:31-40.

29. El-Bassouny D and Essa T. Ultrastructural study on microfold cells and microvillus cells in the follicle-associated epithelium over Peyer's patches in albino rat. The Egyptian Journal of Histology. 2013; 36(4):837-846.

30. da Silva EO, Bracarense APFL and Oswald IP. Mycotoxins and oxidative stress: where are we? World Mycotoxin Journal, 2018; 11 (1): 113-133.

31. 31. Colakoglu F and Donmez HH. Effects of aflatoxin on liver and protective effectiveness of esterified glucomannan in Merino rams. Scientific World Journal. 2012: 462925

32. Pompili S, Sferra R, Gaudio E, Viscido A, Frieri G, Vetuschi A and Latella G. Can Nrf2 Modulate the Development of Intestinal Fibrosis and Cancer in Inflammatory Bowel Disease?. Int J Mol Sci. $2019 ; 20(16)$

33. Fouad AM, Ruan D, El-Senousey HK, Chen W, Jiang $\mathrm{S}$ and Zheng C. Harmful Effects and Control Strategies of Aflatoxin B $\square$ Produced by Aspergillus flavus and Aspergillus parasiticus Strains on Poultry: Review. Toxins (Basel). 2019; 11(3).

34. Li H, Guan K, Zuo Z, Wang F, Peng X, Fang J, Cui H, Zhou Y, Ouyang P, Su G and Chen Z. Effects of aflatoxin B1 on the cell cycle distribution of splenocytes in chickens. J Toxicol Pathol. 2019; 32(1):27-36.

35. Liu C, Zuo Z, Zhu P, Zheng Z, Peng X, Fang J, Cu H, Zhou Y, Ouyang P, Geng Y, Deng J and Sun Y. Sodium selenite prevents suppression of mucosal humoral response by AFB1 in broiler's cecal tonsil. Oncotarget. 2017; 8(33):54215-54226.

36. Lamfon HA. Effect of Selenium on ChlorpyrifosInduced Thyroid Toxicity in Albino Rats. Research in Endocrinology, 2014; (2014): Article ID 751500 .

37. Ezzat S, Nada H, El-Sawy M, El-Shakaa N, Kalleny $\mathrm{N}$ and Zaaki O. Genotoxicity of cadmium in rat lung cells assessed by an alkaline comet assay and the possible protective role of selenium. The Egyptian Journal of Histology. 2012; 35(4):853861

38. Geyikoglu F and Turkez H. Protective Effect of Sodium Selenite on Genotoxicity to Human Whole Blood Cultures Induced by Aflatoxin B1. Brazilian Archives of Biology and Technology. 2005; 48(6):905-910.

39. Bera S, De Rosa V, Rachidi W and Diamond AM. Does a role for selenium in DNA damage repair explain apparent controversies in its use in chemoprevention?. Mutagenesis. 2013; 28(2):127-34. 
الملخص العربى

\section{دراسة هستولوجيه وهستوكيمائية لتاثير افلاتوكسين بيتا 1 على لفائفي الأمعاء الدقيقة لذكور الفئران البيضاء البالغة والدور الوقائي المحتمل لماده سيلينيت الصئيت الصوديوم}

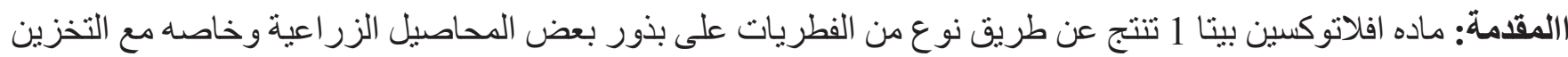

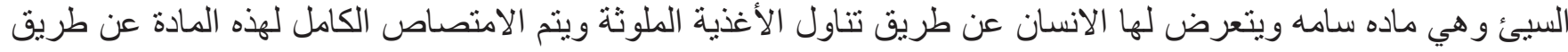

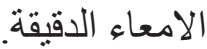
الغرض من البحث: دراسة التأثير الضار لافلاتوكسين بيتا 1 علي لفائفي ذكور الفئران البيضاء البالغة و الحماية المحتملة

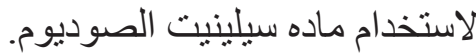

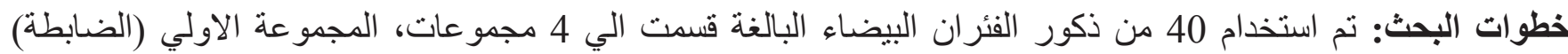

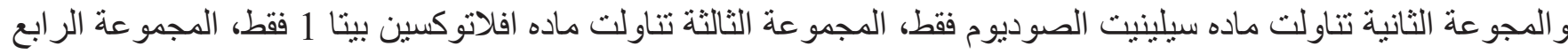

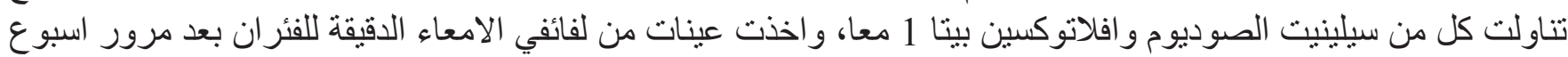

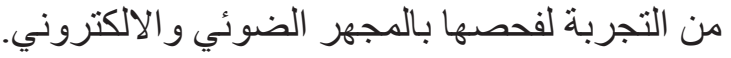

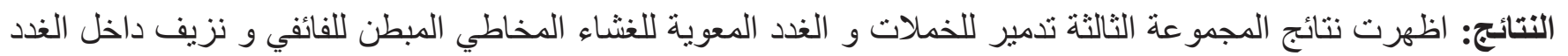

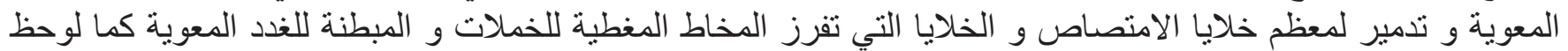

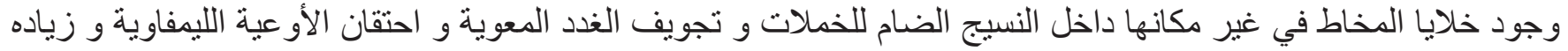

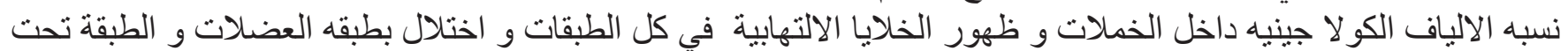

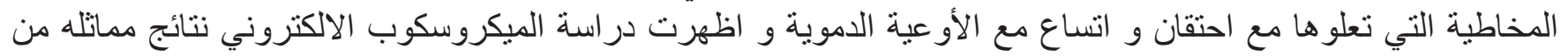

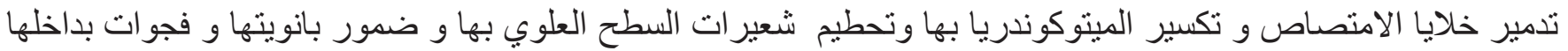

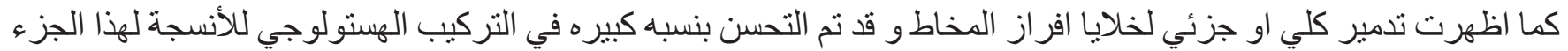

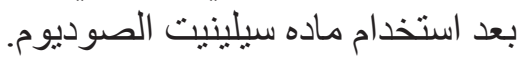

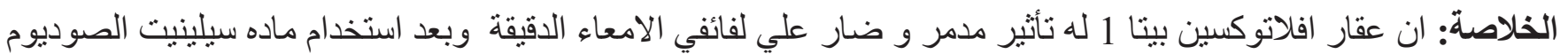

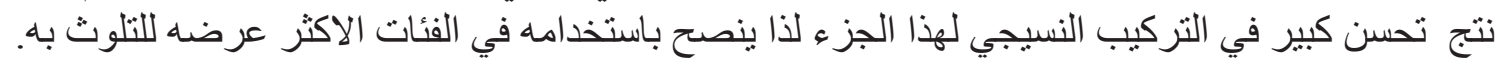

